\title{
Regulating Systemic Risks in the Banking Sector*
}

\author{
Galina Gospodarchuk \\ Department of Finance and Credit \\ Lobachevsky State University of Nizhni Novgorod \\ Nizhny Novgorod, Russian Federation \\ E-mail: gospodarchukgg@iee.unn.ru
}

\author{
Ekaterina Suchkova \\ Banking Department \\ National Research University Higher School of Economics \\ Nizhny Novgorod, Russian Federation \\ E-mail: esychkova@hse.ru
}

\begin{abstract}
The article examines the problems of improving the regulation of systemic risks with regard to the specific features of national economies. The aim of the study is to develop a conceptual platform for the correction of instruments for regulation of institutional systemic risks and its testing in Russian context. The study is based on the analysis of the Basel III regulatory requirements and the practice of their application in the EU and Russia. The study includes the analysis of the national characteristics of the development of the Russian banking system, as well as the analysis of the processes of transformation of the mechanism of formation and accumulation of systemic risks by the banking sector of the Russian Federation. As part of the study, we propose and substantiate the introduction of an additional domestic systemically important capital buffer, which should limit excessive accumulation of systemic risks caused by their recombination and re-concentration. We also identified systemically important Russian banks, which will require this new regulatory tool. The additional domestic systemically important capital buffer proposed in the article will restrict new country-specific sources of accumulation of systemic risks that arise in connection with the change of national macroeconomic and regulatory conditions and manifest in the transformation of business models of banks.
\end{abstract}

Keywords-Basel III; regulation of systemic risks; national features of regulation of systemic risks

\section{INTRODUCTION}

The global financial crisis of 2008 exposed the imperfection of the traditional instruments of banking regulation, their inability to capture accumulating systemic risks. The emergence of a new concept of international banking regulation published by the Basel Committee in 2010 and known as Basel III [1] is the reaction of international banking regulation authorities to the global crisis, which revealed significant drawbacks in supervision of financial markets.

The Basel III document is aimed at increasing the stability of the banking system to shocks and reducing the negative impact of the financial system on the real sector. This agreement contains new regulatory requirements for the capital adequacy of banks, their structure, as well as the requirement for banks to create conservation and

*The study was funded by RFBR according to the research project No 18-010-00232 A - Methodology of multilevel system of diagnostics and regulation of financial stability" year 2018-2020. countercyclical capital buffers.

The key points of the proposed reforms are as follows:

- Basel III introduces a more scrupulous definition of a bank's capital, the higher quality of which implies its greater capacity to absorb losses arising during crisis situations;

- banks have a new requirement for capital adequacy, taking into account the capital conservation buffer at $2.5 \%$ of the total risk-weighted assets. This capital conservation buffer is created to serve as a "safety cushion", necessary to absorb losses arising during financial and economic crises;

- banks are required to form a countercyclical capital buffer [2], which raises the requirements to the level of their capital in the period of economic recovery (up to $2.5 \%$ of total risk-weighted assets) and reducing these requirements (down to $0 \%$ ) during a slowdown in economic growth. Thus, the countercyclical capital buffer is intended to restrain the activity of banks during the "overheating" of the economy and stimulate it during the recession;

- Basel III provides for stricter control measures for systemically important banks [3], whose ability to absorb losses should be higher than that of ordinary banks;

- Basel III framework introduces a leverage indicator at the level not less than $3 \%$ of the ratio of the bank's capital to the total volume of its assets and offbalance non-risk-weighted liabilities. The need to maintain the leverage at a fixed level will limit the market expansion of banks during periods of global economic recovery [4].

In general, we can conclude that Basel III provides for regulation of both market and institutional systemic risks. At the same time, it places much higher requirements on the adequacy and quality of banks' capital in comparison with similar requirements of Basel II, and also modernizes them, introducing absolutely new instruments in response to the challenges of the global economic system. 


\section{APPLICATION OF BASEL III FRAMEWORK IN THE EU AND RUSSIA}

The Basel Committee on Banking Supervision regularly monitors implementation of the Basel III agreement in national jurisdictions, publishing relevant reports, and the latest of which was released in April 2018 [5]. This report reviews the status of adoption of Basel III standards in each jurisdiction of members of the Basel Committee on Banking Supervision. According to the report, all 27 member countries approved national capital requirements, liquidity ratios and introduced rules that establish requirements for a capital buffer. 26 national jurisdictions introduced requirements for a countercyclical buffer, as well as additional requirements for the increase of the capital of systemically important banks.

\section{A. Capital Conservation Buffer}

It is intended to maintain capital adequacy at a certain level in order to cover a bank's losses during the systemic economic recession. It is compiled of the 1 st level capital at $2.5 \%$ of the total assets, weighted against risk. Failure of the banks to comply with the requirements for the formation of a capital conservation buffer entails a restriction on dividend and bonus payments, which should serve as a strong motivation for banks to comply with these requirements.

\section{B. Leverage}

Experts of the Basel Committee call the rapid growth of assets of banks and off-balance liabilities one of the causes of the global financial crisis. In many cases, banks maintain excessive leverage, while observing capital adequacy ratios for risk-weighted assets. The introduction of a simple and fairly transparent indicator of leverage should become additional requirement for the capital of the bank.

The coefficient of leverage is defined as the ratio of tier-1 capital to the total value of assets (including balance sheet and off-balance sheet items) that are not risk-weighted. The minimum requirement for the level of leverage is set at $3 \%$. The indicator of leverage is being gradually introduced by the EU countries and Russia according to the recommendations of the Basel Committee, starting 2017.

\section{Increment to Capital for Systemic Importance}

The most important aspect of Basel III is the more stringent requirements to the capital of global systemically important banks [3], which have a significant impact on the global financial system. Banks identified as systemically important at the global level are ranked into 5 groups according to the level of system importance. For each group, additional requirements for the adequacy of tier 1 capital against risk-weighted assets are established.

At the same time, the Basel Committee on Banking Supervision draws attention to banks that are not identified as systemically important at the global level, but the bankruptcy of which may have a negative impact on the economy of a particular country. In October 2012, the Basel Committee issued a document [6], which defines the work of supervisory bodies with systemically important banks at the domestic level. Credit organizations that can have a serious impact on the stability of the financial system and a country's economy should be identified as domestic systemically important banks, D-SIBs, and special control measures should be applied to them. The practice of implementing domestic approaches to the regulation of systemically important banks requires the introduction of an additional capital buffer for systemically important banks at the domestic level. The size and term for the formation of an additional increment for systemic significance are established by the supervisory authorities of national jurisdictions on their own, based on their own reasoned judgment about the risks that these banks bear for the financial system and the economy of the country [7-22].

The introduction of a capital buffer for systemically important banks is designed to limit the growth of aggregate risk assets in a separate bank. However, this buffer does not take into account the existence of regulatory arbitrage between types of risk assets, which can lead to recombination of risks and their concentration on less regulated areas of activity of banks.

\section{Countercyclical Capital Buffer}

The introduction of a countercyclical capital buffer is necessary to increase the stability of the banking system by accumulating the capital buffer during periods of accelerated growth in the loan offer and, accordingly, the release of the buffer during times of economic stress.

The size and procedure for applying a countercyclical capital buffer for banks are established by the supervisory authorities in national jurisdictions. At the same time, according to the recommendations of Basel III, the value of the countercyclical capital buffer can range from 0 to $2.5 \%$.

The buffer is being introduced gradually - through a transition period from January 1, 2016 to January 1, 2019. In view of the fact that the decision to introduce a countercyclical capital buffer at a non-zero level could have an impact on the development strategy of banks, Basel III recommends to announce the increase of increments in advance.

Regulatory bodies of national jurisdictions themselves determine the size and date of introduction of a countercyclical buffer for banks, based on their own understanding of the phase of the economic cycle in the country.

According to Basel III, calculation of a countercyclical capital buffer of a bank does not include requirements for state organizations, as well as for credit institutions. From the point of view of regulating the cyclical nature of the economic system, this algorithm of calculation seems appropriate. However, from the point of view of supervision over the sources of formation and accumulation of systemic risks, it creates preferences for those risky operations of banks that are excluded from the calculation.

In general, two important conclusions follow from the analysis: 
First, the central banks of different countries, applying the Basel III regulatory requirements for increasing banks' capital, adjust (within the acceptable limits) only the parameters of the proposed Basel III instruments, and also determine the specific terms of their implementation. The adjustment of the parameters and timing of the implementation of regulatory instruments is based primarily on motivated judgments and does not have a clear methodological basis.

Second, systemic risk management tools used by banks operate with cumulative risk of active operations of banks (with the exception of countercyclical buffer) and, thus, do not take into account the likelihood of the emergence of new sources of risks as a result of transformation of the banks' business models.

These findings show that, in order to further develop the regulatory reform, it is necessary to develop a conceptual basis for adjusting the tools for regulating systemic risks, taking into account the processes of recombination and reconcentration of risks in the banking systems of countries.

\section{CONCEPTUAL PlATFORM FOR CORRECTION OF} INSTRUMENTS OF REGULATION OF SYSTEMIC RISKS TAKING WITH REGARD TO NATIONAL FEATURES

When developing the conceptual platform, we proceed from the following:

- Institutional systemic risks are formed and accumulated in the banking system.

- The mechanism of formation and accumulation of systemic risks in the banking sector is specific for each country and tends to transform under the influence of changes in the macroeconomic and regulatory environment.

- Transformation of the mechanism of formation and accumulation of systemic risks manifests itself in the recombination and re-concentration of individual risks and is reflected in the restructuring of risky active banks.

- Restructuring of banks' risky assets may lead to an increase in systemic risks, if the accelerated growth of certain types of risk assets is accompanied by an increase in their respective risks.

- Accelerated concentration of risks within certain types of active banking operations indicates the need for additional regulatory measures that limit this process.

- Taking into account that macroeconomic and regulatory environment reflects the national peculiarities of the development of countries; we believe that the adjustment of the instruments for regulating systemic risks taking into account recombination and the re-concentration of individual risks should be conducted at the level of national jurisdictions.
Based on these assumptions, the correction of institutional systemic risk management instruments by central banks of different countries should be carried out in accordance with the change in the mechanism of formation and accumulation of risks. At the same time, the correction of regulatory instruments can consist both in adjusting the parameters of the regulatory instruments recommended by Basel III and in using new additional instruments that limit the level of systemic risks in the banking sector. Since the first approach is already being used by the central banks of different countries and at the same time does not fully provide the stability of national banking systems, it becomes feasible to develop a new regulatory instrument - additional domestically important capital buffer, which will provide for the absorption of losses from the potentially risky transformation of the business models of banks. The size of the additional capital buffer should be calculated in relation to not all of the risky assets, but only to those that show significant growth accompanied by an accelerated increase in the magnitude of the risks. At the same time, the exceeding of the normative level of the gap (the difference between the rate of growth in the level of risks for a particular type of active operations and the rate of growth in the share of these operations in the bank's assets) by a certain bank should become a signal to introduce this capital buffer.

It is logical to assume that the size of this buffer and the conditions (criteria) for its use must be different in different countries. However, the need to take into account changes in the mechanism of formation and accumulation of systemic risks should, in our opinion, be reflected in the recommendations of international financial organizations in the form of a methodological platform for adjusting the instruments for regulating systemic risks within the national jurisdictions.

Thus, we come to the conclusion that one of the principles of adjusting the tools for regulating systemic risks, taking into account the national characteristics of countries, should be the principle of limiting the processes of transformation of the mechanism of formation and accumulation of systemic risks, which lead to an increase in its risk probability. And the most preferred instrument used for these purposes is the introduction of a domestic systemically important capital buffer, which is dynamic and adaptive in nature.

\section{SOME PRACTICAL Aspects of the APPLICATION OF THE PROPOSED CONCEPT TO THE REGULATION OF SYSTEMIC RISKS IN RUSSIA}

A vivid example confirming the need to introduce a new regulatory instrument within the framework of national jurisdiction can be the situation in the Russian Federation in 2017.

During this period, the Bank of Russia identified problems with the quality of assets in three large banks (Otrkrytie Bank, Promsvyazbank, and BINBANK). The state is the majority shareholder in these banks, which are ranked 6,10 and 12 in terms of assets, respectively. This entailed additional supplementing of reserves and increase of losses 
in these banks. The losses of Otkrytie were caused mainly by the revaluation of securities. The revaluation was related to the value of Eurobonds of Russia with pay off in 2030 ("Russia 30"), as the bank had more than half of its equity offering on its balance sheet. A significant amount of reserves was additionally provided against loans to other banks ( 2.8 billion rubles.) and loans to corporate customers (3.8 billion rubles.). As a result of the loss of August 28, 2017, the capital adequacy ratio fell below allowable values.

On the eve of the resolution, Binbank had 31 billion rubles invested in mutual investment funds, as well as 17.4 billion rubles of shares in subsidiaries. This accounted for more than half of the capital ( 94.3 billion rubles). In addition, Binbank had more than 500 billion rubles of investments in the troubled "Rost-Bank", while being in charge of the resolution of this bank. We should note that Binbank did not create reserves for this loan, which, in our opinion, was the main threat to capital.

The drop in the quality of securities of Otkrytie and BINBANK negatively affected other credit institutions, and primarily Promsvyazbank and Moscow Credit Bank, which are systemically important.

Since August 2017, the Central Bank announced the reorganization of Otkrytie, Binbank and Rost Bank funded by Binbank, as well as Promsvyazbank. As of today, the Banking Sector Consolidation Fund (controlled by the Central Bank) is in charge of resolution of the Otkrytie group, which includes three banks - FC Otkrytie, Trust and Rosgosstrakh Bank, the Binbank group, which includes Binbank, Rost Bank and Binbank Digital, and Promsvyazbank.

The resolution of the three largest banking groups in Russia cost the Central Bank almost 2.62 trillion rubles. ${ }^{1}$ At the same time, the Central Bank contributed 758.3 billion rubles to the capital of resolved banks. They also received 1.86 trillion rubles in the form of deposits.

Disruption of financial stability of the three largest banking groups had a major impact on the entire banking sector. In the third quarter of 2017, the banking sector recorded a loss of 96 billion rubles (without taking into account the losses of resolved banks). The resulting losses have reduced financial stability, both for the entire banking sector and for individual banks, primarily private ones (see "Fig. 1").

1 http://polit.ru/news/2018/06/06/cbr/ 


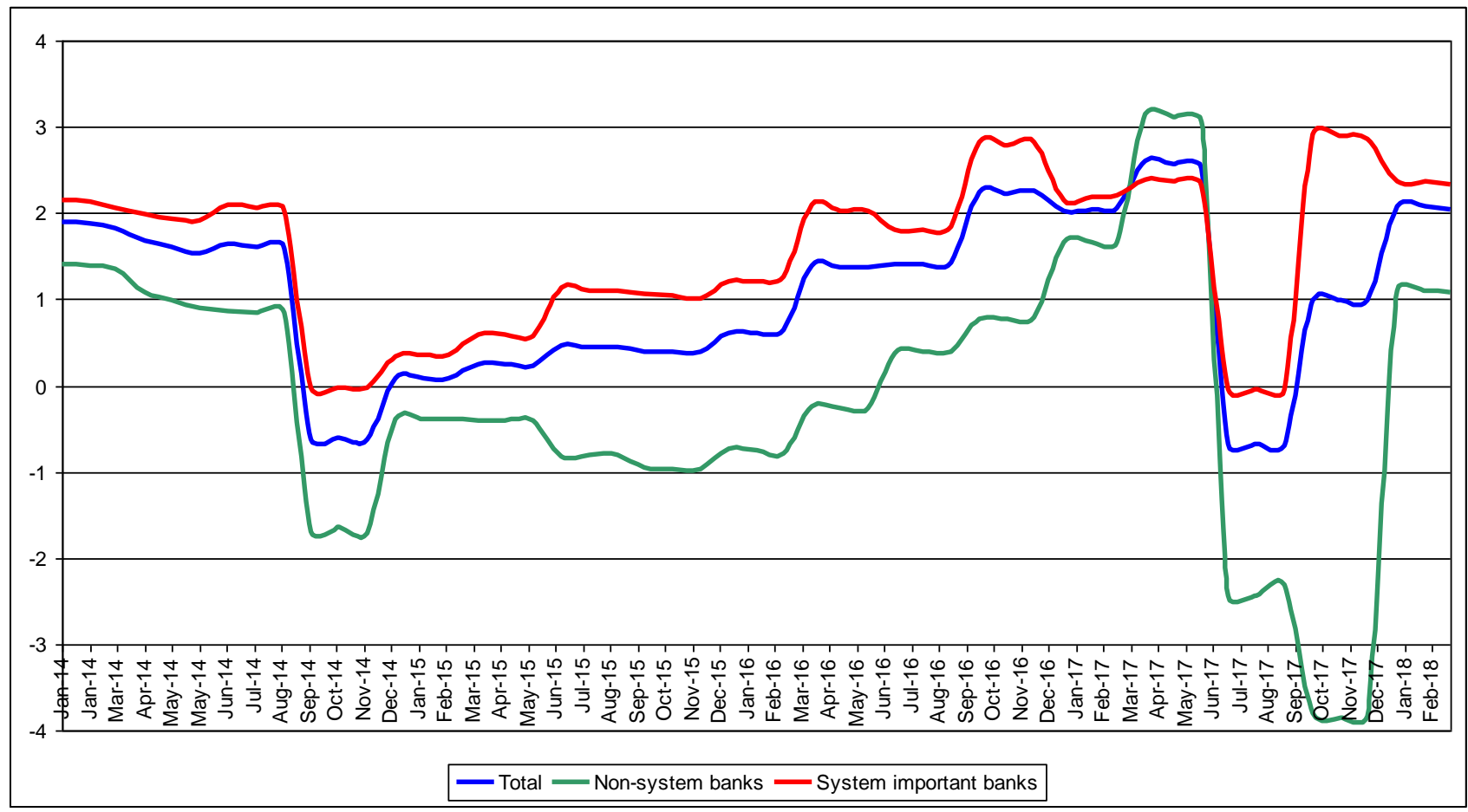

Fig. 1. Dynamics of the financial stability index of all banks, state banks, banks with foreign participation, and other banks. ${ }^{2}$

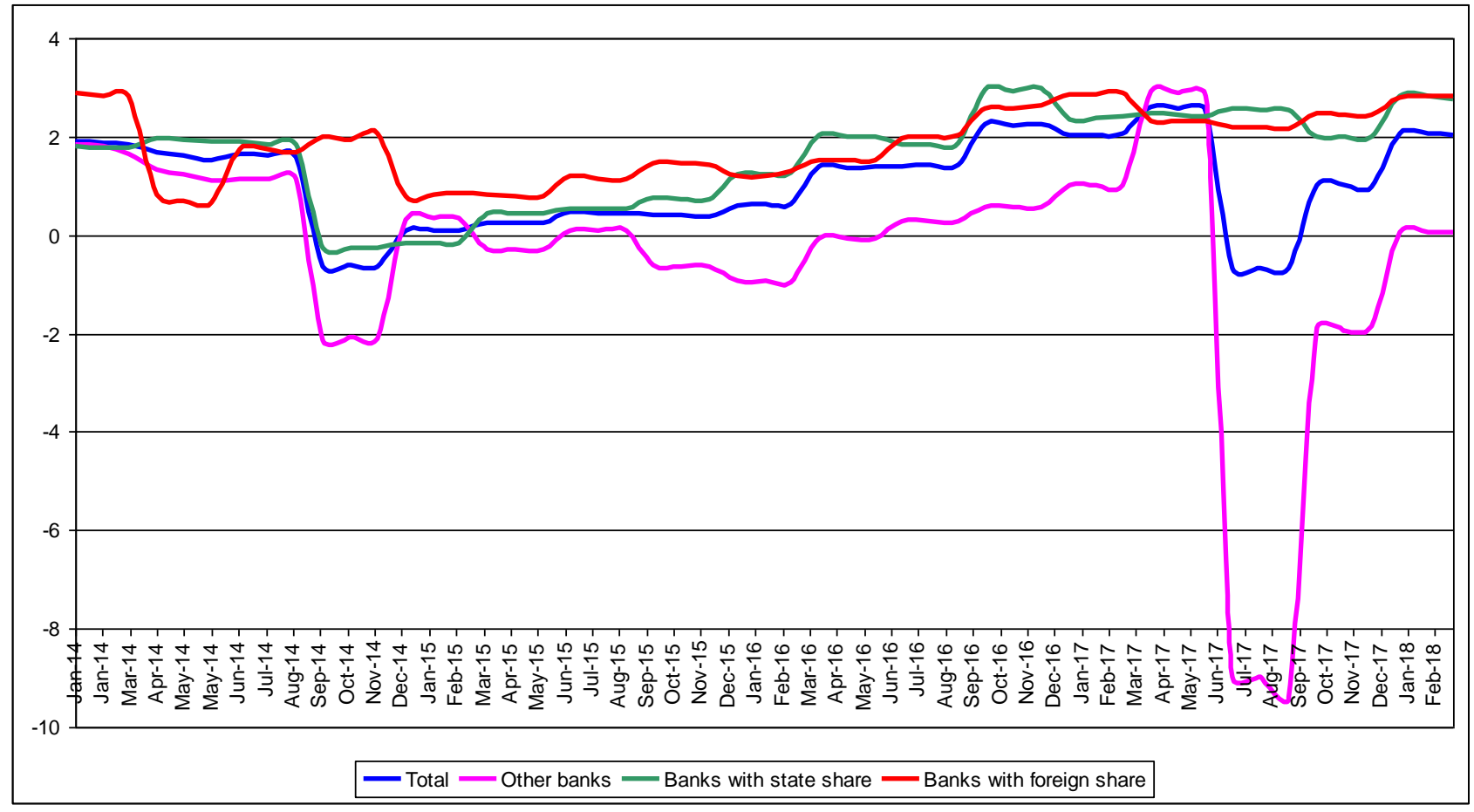

Fig. 2. Dynamics of the financial stability index of all banks, systemically important banks and other banks. 
At the same time, due to state support, the financial stability of systemically important banks decreased less significantly than that of other banks (see "Fig. 2").

It is important to note that the first signs of transformation of the mechanism of formation and accumulation of systemic risks in the Russian banking system appeared as early as in 2015. These include the formation of the following trends.

\section{A. The Growing Asymmetry Between the Growing Assets of the Banking System and Economic Growth}

Despite the prolonged global crisis and the national crisis of 2014-2015, the assets of the Russian banking system showed significant growth, which is clearly visible from the graph presented in "Fig. 3". The increase in the assets of the banking system itself indicates its development over the analyzed period, which can be considered a positive trend. However, comparison of the growth rates of the assets of the banking system with the growth rates of the gross domestic product (both nominal and real) shows not only the presence of asymmetry between them, but also its strengthening.

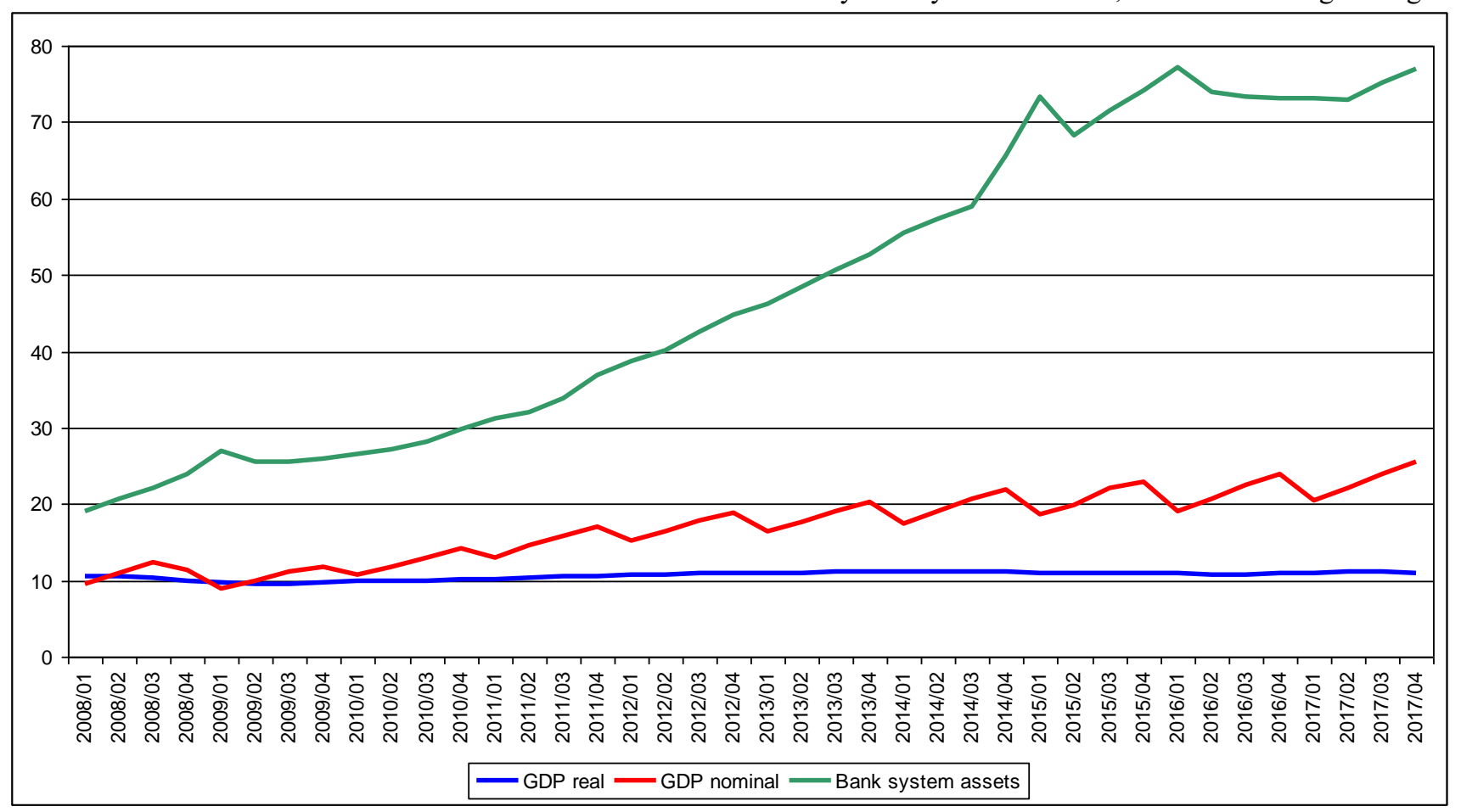

Fig. 3. Change in nominal GDP, real GDP (in 2008 prices) and assets of the banking system (BS) from 01.01.2008 to 01.01.2018.

Real GDP adjusted for the seasonal factor provided at the Rosstat website http://www.gks.ru/free_doc/new_site/vvp/kv/tab7.htm

Data are combined from two tables - in 2008 and 2016 prices. GDP for 2011 was present in both sets of data, which allowed us to find the price conversion factor for 2016 in 2008 prices, which was 1.98999 .

Nominal GDP provided by the website of Rosstat http://www.gks.ru/free_doc/new_site/vvp/kv/tab5.htm

d. Since 2011, data are calculated according to a new methodology, which gives a higher estimate of GDP. To bring the old data for 2008-2010 to a comparable type, they were multiplied by a factor of

Accelerated growth of bank assets in comparison with economic growth indicates a decrease in the role of the banking system in the economic development of the country. The reasons for this phenomenon can be as follows:

- reduced share of operating assets, including through the formation of additional reserves;

- reduced share of investment loans to non-financial corporations in the aggregate loan portfolio of the banking system;

- low efficiency of investment projects financed by banks;
Assets of the banking system according to kuap.ru

- transition of banks to the savings model of behavior by increasing the share of assets held on the correspondent accounts of the Bank of Russia;

- increased interest in the instruments of the financial market, which foster the development of financial corporations.

In general, the growing asymmetry between the development of the banking system and the development of the economy shows that the banking sector is beginning to switch from being a source of long-term funding of the real sector of the economy to serving as a source of funding for the financial market infrastructure. 


\section{B. Restructuring of Assets of the Banking System}

Crisis phenomena in the economy and the introduction (according to the Bank of Russia's announcement of the imminent introduction) of new regulatory requirements affected the structure of the assets of the banking system. Among the main factors that influenced the investment of funds by commercial banks in the period 2014-2017, the following can be singled out:

- weak economic dynamics, which objectively narrows the ability of banks to invest money and make profit;

- deteriorating financial condition of potential borrowers affected by the crisis phenomena in the economy;

- high debt load in traditional sectors for bank lending;
- continuing restrictions on access of commercial banks to external financial markets;

- disproportionate regulation of professional participants in the financial market, which makes the parallel banking system more attractive for borrowers;

- rapid development of technologies in the financial sector, which triggered the emergence of new participants (for example, retailers) in the financial market;

- disproportionate regulation of investment operations of banks.

Over the analyzed period, the risk assets were growing mainly against lending growth within the banking sector and growth in operations with securities (see "Fig. 4").

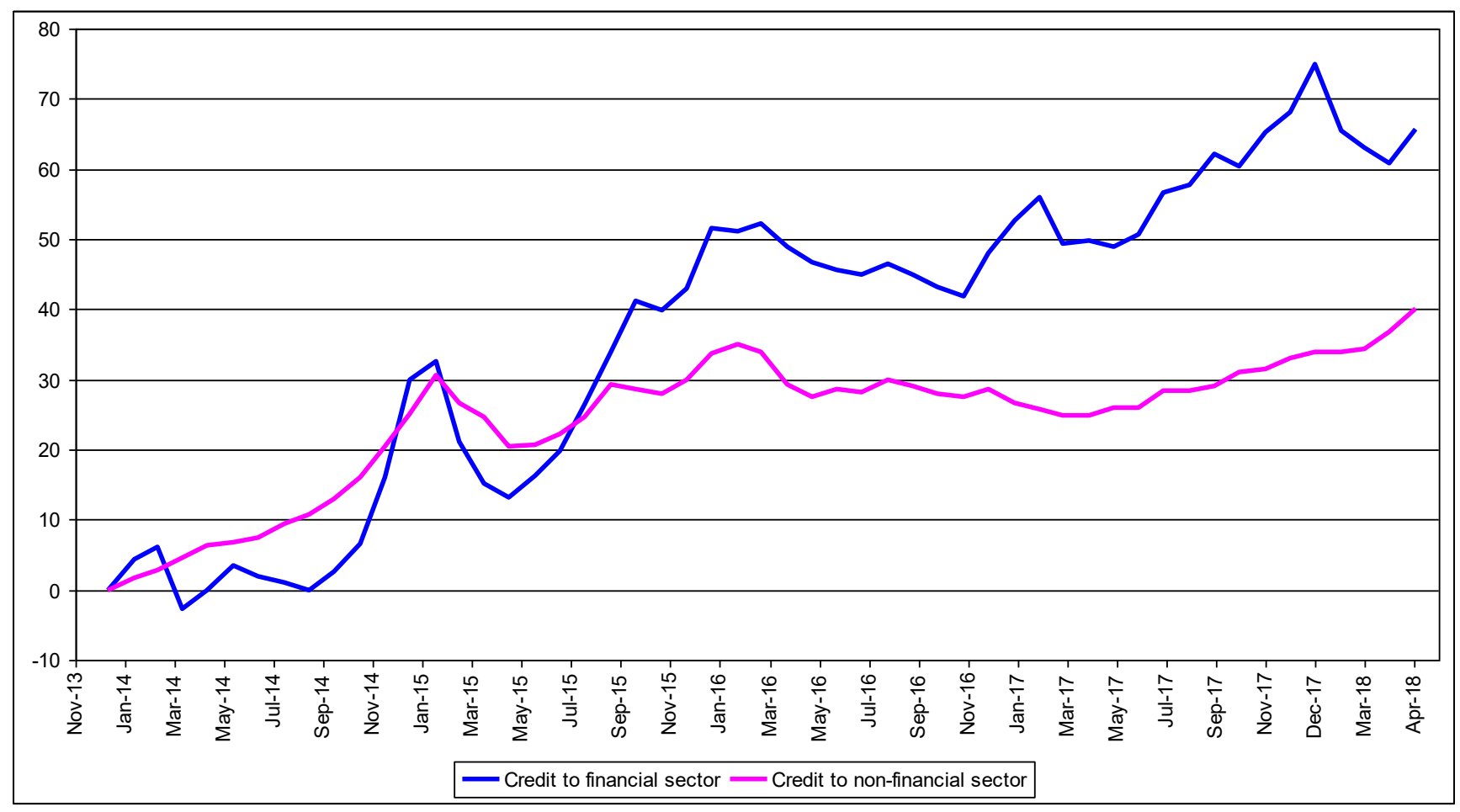

Fig. 4. Growth rate of loans to credit institutions and securities transactions and growth rates of loans to the non-financial sector of the economy.

At the same time, the largest contribution to the formation of this gap was made by loans to credit institutions. So from 01.01 .2014 to 01.01 .2018 , the growth rate of loans to credit institutions calculated on a cumulative total is increased by 2 times. At the same time, the increase in loans to non-financial companies and individuals did not exceed $25 \%$ for the entire analyzed period (see "Fig. 5 "). 


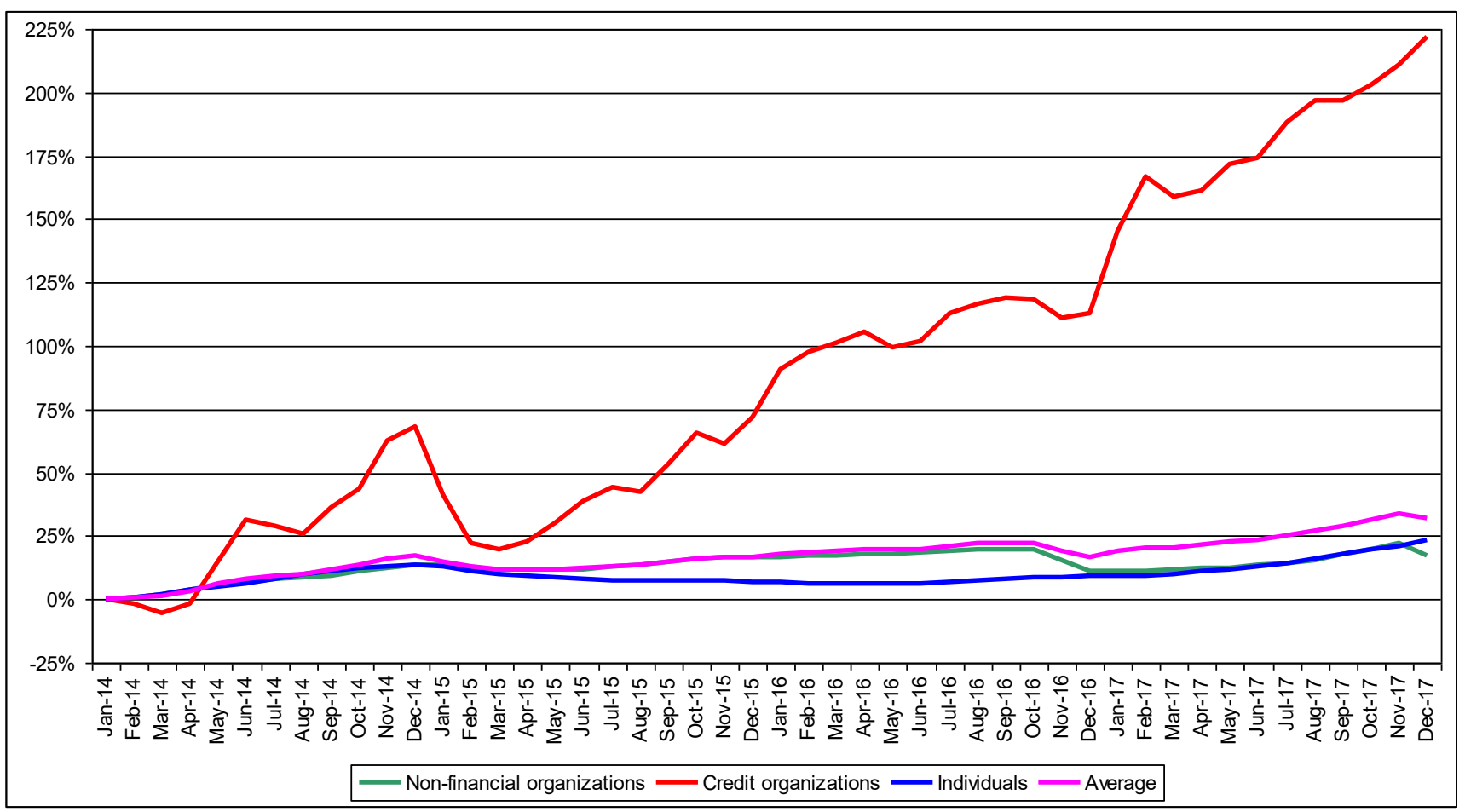

Fig. 5. The growth rate of loans to non-financial organizations, credit organizations and individuals.

Accelerated growth in lending operations of credit institutions and securities transactions led to a change in the structure of the consolidated balance of the banking system (see "Table I").

TABLE I. Share OF INDIVIDUAL TRANSACTIONS IN BANKING SyStem ASSETS, \%

\begin{tabular}{|c|c|c|c|c|c|c|c|}
\hline Transaction type & 01.01 .14 & 01.01 .15 & 01.01.16 & 01.01.17 & 01.01.18 & 01.05.18 & $\begin{array}{l}\text { Change over the } \\
\text { period, pp. }\end{array}$ \\
\hline Transactions in securities & 13.1 & 11.8 & 13.4 & 13.5 & 13.5 & 13.9 & +0.8 \\
\hline Loans to credit organizations & 10.4 & 10.8 & 11.6 & 13.1 & 15.1 & 12.7 & +2.3 \\
\hline Loans to non-financial organizations & 41.0 & 39.6 & 42.0 & 41.2 & 39.7 & 40.8 & -0.2 \\
\hline Loans to individuals & 17.1 & 14.1 & 12.3 & 13.1 & 14.2 & 14.8 & -2.3 \\
\hline
\end{tabular}

At the same time, growing lending operations of credit institutions and securities transactions were accompanied by an even greater increase in overdue debt on these transactions (see "Table II")

TABLE II. OVERdue Debts For Certain Types of Active Operations, MLn. Rub.

\begin{tabular}{|l|l|l|l|l|l|l|l|l|}
\hline \multicolumn{1}{|c|}{ Transaction type } & \multicolumn{1}{|c|}{$\mathbf{0 1 . 0 1 . 1 4}$} & $\mathbf{0 1 . 0 1 . 1 5}$ & $\mathbf{0 1 . 0 1 . 1 6}$ & $\mathbf{0 1 . 0 1 . 1 7}$ & $\mathbf{0 1 . 0 1 . 1 8}$ & $\mathbf{0 1 . 0 5 . 1 8}$ & $\begin{array}{c}\text { Change, } \\
\text { mln. rub. }\end{array}$ & \multicolumn{1}{c|}{ Change, \% } \\
\hline Transactions in securities & 6326 & 5197 & 6138 & 14220 & 30964 & 44991 & 38664 & $611.2 \%$ \\
\hline $\begin{array}{l}\text { Loans to credit } \\
\text { organizations }\end{array}$ & 13409 & 54231 & 64064 & 89338 & 146542 & 150519 & 137110 & $1022.5 \%$ \\
\hline $\begin{array}{l}\text { Loans to non-financial } \\
\text { organizations }\end{array}$ & 949453 & 1297976 & 2087165 & 1906600 & 2079664 & 2335658 & 1386205 & $146.0 \%$ \\
\hline Loans to individuals & 486470 & 742145 & 952473 & 913387 & 920127 & 889643 & 403172 & $82.9 \%$ \\
\hline
\end{tabular}

It is important to note that the growth rate of overdue debt significantly exceeded the rate of growth in the volume of related transactions (gap). The data in "Table III" shows that the final gap has a positive value for all types of analyzed operations. At the same time, the gap reaches its maximum values with credit operations of credit institutions and operations with securities. This indicates that these operations are sources of formation and accumulation of systemic risks in the banking system of Russia. 


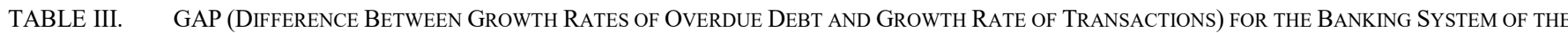
RUSSIAN FEDERATION, P.P.*

\begin{tabular}{|l|l|l|l|l|l|}
\hline \multicolumn{1}{|c|}{ Transaction type } & 01.01 .14 & 01.01 .15 & 01.01 .16 & 01.01 .17 & 01.01 .18 \\
\hline Transactions in securities & -0.39 & -0.49 & +0.86 & 01.05 .18 & +3.41 \\
\hline Loans to credit organizations & +2.63 & +3.19 & +4.96 & +8.84 & +5.56 \\
\hline Loans to non-financial organizations & +0.07 & +0.74 & +0.65 & +0.79 & +9.44 \\
& & & +0.39 & +2.63 \\
\hline Loans to individuals & +0.41 & +0.93 & +0.84 & +0.69 & +0.56 \\
\hline
\end{tabular}

To confirm this conclusion, we conducted a similar analysis for systemically important banks (SIBs). "Table IV" shows that the restructuring of assets towards increasing the share of lending operations of credit institutions and securities operations occurs only in 10 out of 14 analyzed banks. At the same time, banks that were resolved in 2017 showed the most significant increase in the share of these operations, which exceeded the indicators for the banking system by several times. So for the period from 01.01.2014 to 01.01 .2018 Otkrytie increased the share of these transactions in its assets by 26.3 points, Promsvyazbank by 11.8 points, while the average increase of this indicator was at 5.1 points. At the same time, the share of these operations at Binbank from 01.01.14 to 01.11.2016 increased by $58.1 \%$.

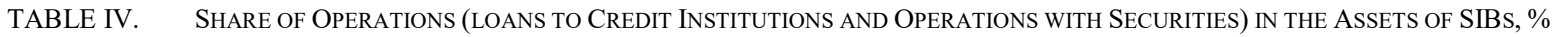

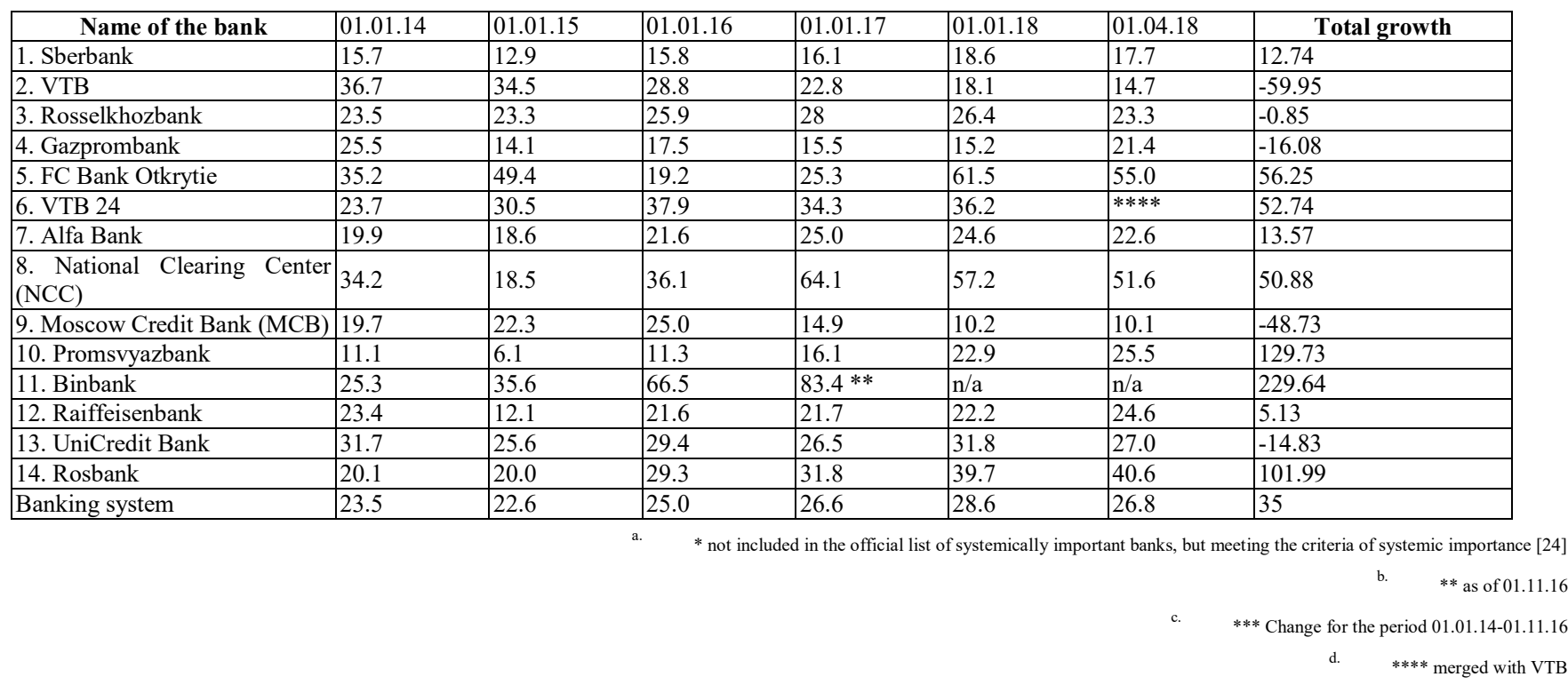

For a better visual assessment of risk transformation processes of systemically important banks we used graphical analysis, which allows to assess the recombination of risks simultaneously in two fields: growth of overdue debt and change in the structure of assets (increase in the share of loans to credit institutions and operations with securities) ${ }^{3}$ (see "Fig. 6").

In "Fig. 6", the horizontal axis reflects the growth of overdue debt of the analyzed banks for the period from 01.01.2016 to 01.01.2018; the vertical axis represents the growth in the share of loans to credit institutions and securities operations for the same period.

The obtained values on the graph are divided into 4 clusters depending on the level of systemic risk of the bank. The boundaries of clusters were defined as follows: banks

The graph shows 14 analyzed banks that show a growth rate of overdue debt of more than $20 \%{ }^{4}$ for the analyzed period are characterized by a high level of assumed risks. The boundary of this indicator for "growth rate of share of loans to credit institutions and operations with securities" is set at $26 \% 5$.

It is worth noting that the boundaries of clusters are flexible and subject to change following the change in the structure of the banking system. 


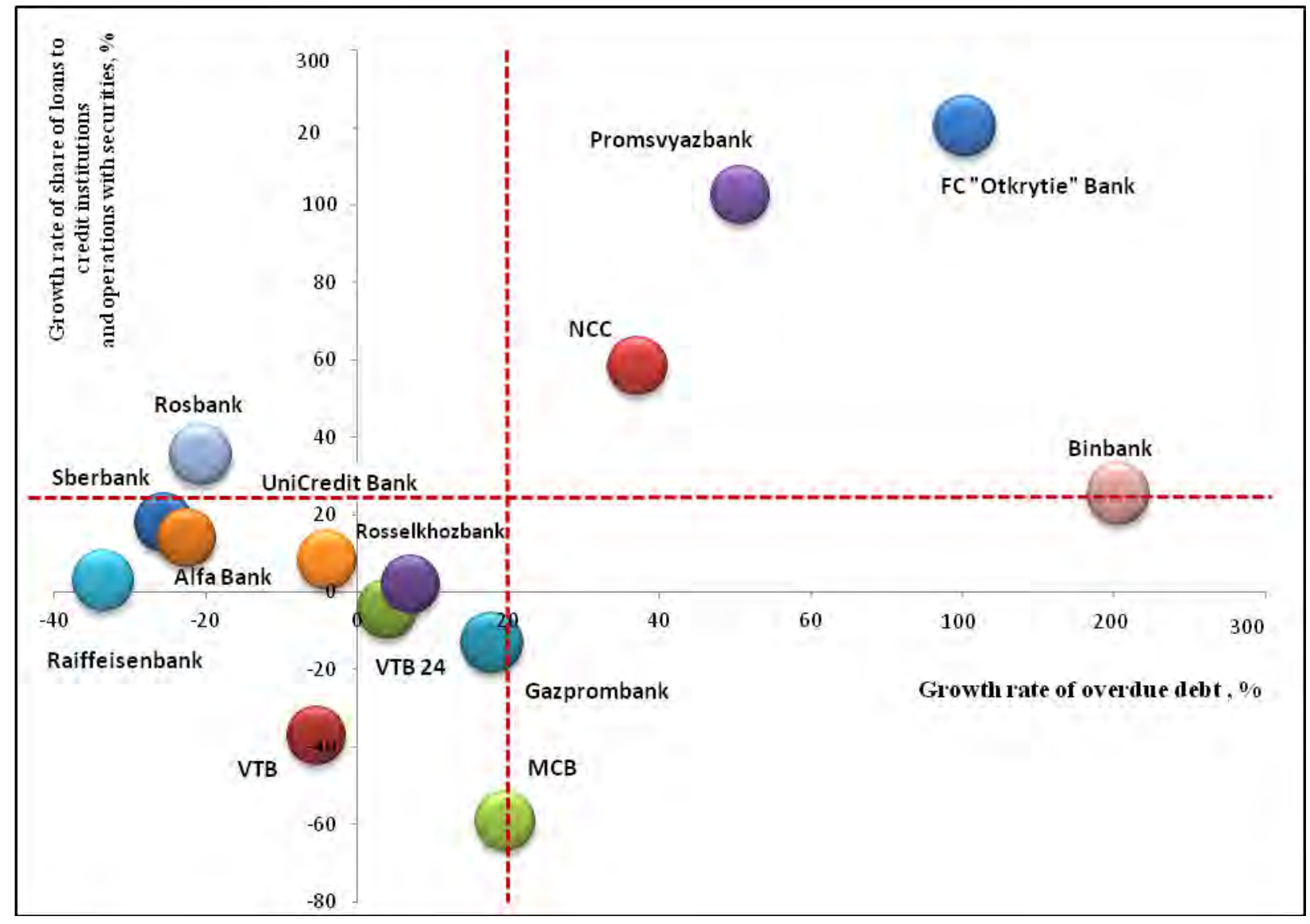

Fig. 6. Distribution of SIBs by risk zones.

"Fig. 6" demonstrates that systemically important banks, which experienced resolution in 2017, were the institutional sources of systemic risk in area of "Interbank lending operations and operations with securities", which meant that the additional special regulatory tools had to be applied. We believe that timely introduction of additional domestics systemically important capital buffer for these banks would help avoid resolution or significantly reduce the damage caused by these banks both to the financial sector and to the economy as a whole.

In conclusion, it should be noted that in the framework of this study, we did not set the task of developing quantitative values for an additional domestic systemically important capital buffer, as well as formalizing the conditions for its application. We believe that this task can become a topic for a further research in this area.

\section{CONCLUSION}

The conducted research can be generally concluded as follows:

In order to increase the effectiveness of systemic risk regulation, Basel III places much higher requirements on the adequacy and quality of banks' capital in comparison with similar requirements of Basel II, and also modernizes them, introducing absolutely new instruments in response to the challenges of the global economic system.
The central banks of different countries, applying the Basel III regulatory requirements for increasing the banks' capital, adjust (within the acceptable limits) only the parameters of instruments proposed by Basel III, and also determine the specific terms of their implementation. The adjustment of the parameters and timing of the implementation of regulatory instruments is based primarily on motivated judgments and does not have a clear methodological basis.

The instruments for regulation of systemic risks used by central banks operate with the aggregate risk of active operations of banks (with the exception of a countercyclical buffer) and, therefore, do not take into account the likelihood of emergence of new sources of risk arising as a result of transformation of business models of banks.

As a new methodological approach to the regulation of systemic risk within national jurisdictions, it is advisable to use a concept that takes into account the peculiarities of the transformation of the business models of banks under the influence of changes in national macroeconomic and regulatory environment, which can lead to recombination and re-concentration of risks, both at the level of individual banks, and at the level of national banking systems.

Within the framework of the proposed Concept, in order to limit the growth of risk probability of national banking systems, it is preferable to use a new regulatory tool - an 
additional domestic systemically important capital buffer, which is dynamic and adaptive in nature. The size of additional capital buffer should be calculated in relation not to all risky assets, and only to those that lead to restructuring and re-concentration of risks in the banking system.

The results of approbation of the proposed Concept under Russian conditions confirmed its practical applicability and expediency of application in order to timely limit the growth of risk probability of the national banking system.

\section{REFERENCES}

[1] Basel Committee on Banking Supervision (2010 December). Basel III: A global regulatory framework for more resilient banks and banking systems. Retrieved from https://www.bis.org/publ/bcbs189_dec2010.pdf.

[2] Basel Committee on Banking Supervision (2010). Guidance for national authorities operating the countercyclical capital buffer. Retrieved from https://www.bis.org/publ/bcbs187.pdf.

[3] Basel Committee on Banking Supervision (2013). Global systemically important banks: updated assessment methodology and the higher loss absorbency requirement. Retrieved from https://www.bis.org/publ/bcbs255.pdf.

[4] Basel Committee on Banking Supervision (2014). Basel III leverage ratio framework and disclosure requirements. Retrieved from https://www.bis.org/publ/bcbs270.pdf.

[5] Basel Committee on Banking Supervision (2018). Fourteenth progress report on adoption of the Basel regulatory framework. Retrieved from https://www.bis.org/bcbs/publ/d440.pdf.

[6] Basel Committee on Banking Supervision (2012). A framework for dealing with domestic systemically important banks. Retrieved from https://www.bis.org/publ/bcbs233.pdf.

[7] Basel Committee on Banking Supervision (2016). Regulatory Consistency Assessment Programme (RCAP) - Assessment of Basel III G-SIB framework and review of D-SIB frameworks - European Union. Retrieved from https://www.bis.org/bcbs/publ/d372.pdf.

[8] European banking authority (2014 December). On the criteria to determine the conditions of application of Article 131(3) of Directive 2013/36/EU (CRD) in relation to the assessment of other systemically important institutions (O-SIIs). Retrieved from https://www.eba.europa.eu/documents/ 10180/930752/EBA-GL2014-10+(Guidelines+on+O-SIIs+Assessment).pdf.

[9] Bank of Russia (2015). On the methodology for determining systemically important credit institutions. Directive no. 3737-U by 22.07.2015

[10] Bank of Portugal (2016 July). Identification of other systemically important institutions (O-SIIs) and calibration of O-SII capital buffers. Retrieved from https://www.bportugal.pt/sites/ default/files/anexos/doc_osii_en_0.pdf.

[11] German Federal Financial Supervisory Authority (2017 July). Main features of the method for the identification of other systemically important institutions (O-SIIs). German Banking Act, section 10g (2). Retrieved

https://www.bundesbank.de/Redaktion/EN/Topics/2017/

2017_11_30_capital_add_ons_systemically_important_institutions.ht $\mathrm{ml}$.

[12] Bank of England and the Prudential Regulation Authority (2016 February). The PRA's approach to identifying other systemically important institutions (O-SIIs). Retrieved from https://www.bankofengland.co.uk/-/media/boe/files/prudentialregulation/policy-statement/ 2016/ps616.

[13] Central Bank of Malta and Malta Financial Services Authority (2015 December). On the methodology for the identification of other systemically important institutions and the related capital buffer calibration. Directive no. 11 and MFSA banking rule 15. Retrieved from
https://www.mfsa.com.mt/pages/readfile.aspx?f=/files/Announcement s/Consultation/Feedback/Policy\%20document\%20O-SII.pdf.

[14] Committee on Systemically Important Financial Institutions in Denmark (2013 March). Systematically Important Financial Institution in Denmark: identification, requirements and crisis management. Retrieved from https://em.dk/english/ /media/files/2013/report-sificommittee.ashx?la=en.

[15] Central Bank of Ireland (2015). Identification of other systemically important institutions in Ireland and announcement of associated buffers. Retrieved from https://www.centralbank.ie/docs/defaultsource/financial-system/financial-stability/macroprudentialpolicy/other-systemically-important-institutions/o-sii-announcementnovember-2017.pdf?sfvrsn=4

[16] Central Bank of Estonia (2016). Systemic risk buffer and other systemically important institutions buffer. Analysis of the setting of the buffer requirements in Estonia. Retrieved from https://www.esrb.europa.eu/pub/pdf/other/20160426_eesti_pank_srb analysis.en.pdf?9d41d1d230b86cd011e8f87c520fa189.

[17] National Bank of Romania (2017). On the methodology and procedures used for setting capital buffers and the scope of these instruments. Retrieved from www.cnsmro.ro/content/reg-2-2017en.pdf.

[18] Polish Financial Supervision Authority (2016). Other systemically important institutions (O-SIIs). Retrieved from https://www.knf.gov.pl/knf/en/komponenty/img/Other_systemically_i mportant_institutions_14_11_16_48624.pdf.

[19] Skořepa M. and Jakub S. (2013). An additional capital requirement based on the domestic systemic importance of a bank. Czech National Bank Financial stability report 2012-2013, pp. 96-102. Retrieved from http://www.cnb.cz/en/financial stability/fs reports/fsr 20122013/fsr_2012-2013_article_i.pdf.

[20] Central Bank of Slovak Republic (2016). Domestic systemically important institutions - determination and setting of capital buffers. Retrieved http://www.nbs.sk/ img/Documents/ Dohlad/Makropolitika/OSII_dodatocne_informacie_EN_1.pdff.

[21] National Bank of Belgium (2016). Annual disclosure regarding the designation of and capital surcharges on Belgian O-SIIs. Retrieved from

https://www.nbb.be/doc/cp/eng/2017/annual_disclosure_osills_01122 017.pdf.

[22] Central Bank of Cyprus (2017). Policy for the designation of Cyprus Investment Firms that meet the definition of Other Systemically Important Institutions (O-SIIs) and the methodology for the determination of the O-SII buffer requirement of each Cyprus investment firm. Retrieved from https://www.centralbank.cy/images/media/pdf/OSII_buffer_policy_CIFs_-_2016_-_EN_.pdf.

[23] Gospodarchuk G., Gospodarchuk S. (2017). Assessment of Financial Stability of Banking Systems. Open Review of Management, Banking and Finance vol. 3, issue 2, pp 6-24. Retrieved from https://openreviewmbf.org/issues/.

[24] Gospodarchuk G., Suchkova E. (2017) The Improvement of Criteria for Identification of Systemically Important Banks Based on CrossSectoral Approach. Finance: Theory and Practice. vol. 22, issue 4, pp 18-37. Retrieved from https://financetp.fa.ru/jour/article/view/731/500 